\title{
10 Years of research in Gesäuse National Park: An overview of the research publi- cations of the young protected area
}

\author{
Alexander Maringer \& Daniel Kreiner
}

Keywords: protected area, national park, Natura 2000, research topics, Austria

\section{Abstract}

Gesäuse National Park, Austria's youngest national park, was established in 2002.

The protected area covers $113 \mathrm{~km}^{2}$ and is characterized by its main habitats of rock, alpine meadows, forests and aquatic habitats. High relief intensity shapes the scenery. Between 2003 to 2013, induced by the conservation authorities, 366 authors created a total of 309 research reports. The main focus is on management-relevant research topics as well as on vertebrates and higher plants within the forests.

Profile

Protected area

Gesäuse NP

Mountain range

Alps

Country

\section{Austria}

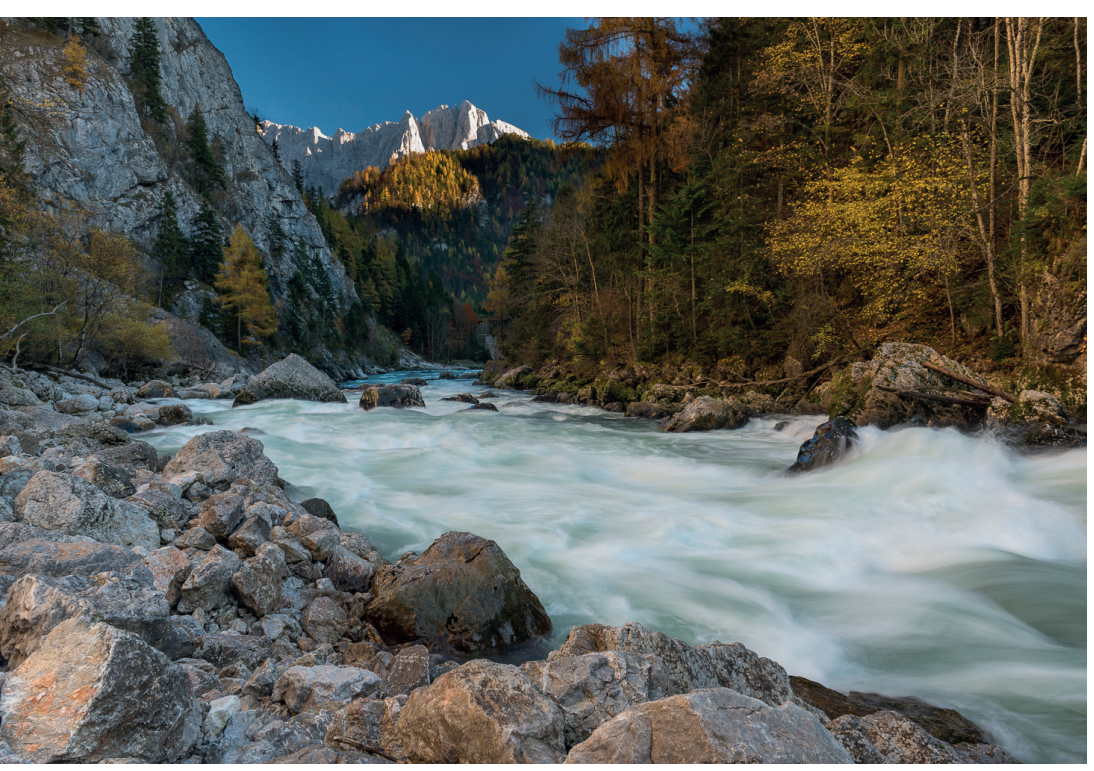

Figure 1 - Gesäuse NP, hotspot of endemic species and bighly dynamic processes. (C) Andreas Hollinger, Nationalpark Gesäuse Archiv

\section{Introduction}

Gesäuse National Park (NP) was founded on 26 October 2002 and shortly after accepted as an IUCN Category II protected area. The NP forms the core of the Natura 2000 area Ennstaler Alpen \& Gesäuse. The Gesäuse is a water gap of the river Enns in the northeastern part of the Ennstal Alps in the Austrian federal province of Styria. The NP covers $113 \mathrm{~km}^{2}$ and reaches from $490 \mathrm{~m}$ (Enns at Hieflau) up to an altitude of $2369 \mathrm{~m}$ (Hochtor). High relief energy characterizes the main habitats of rock, alpine meadows, forest and aquatic areas.

The rugged peaks of the Hochtor, Buchstein and Reichenstein ranges are made of Dachsteinkalk lime- stone and dolomite. The comparatively fast weathering of the dolomites creates extensive debris chutes and the steep slopes encourage dynamic natural processes such as avalanches and landslides. Situated on the edge of the Alpine glacial shield during the last ice age, the Gesäuse has retained a particularly high number of 73 endemic species (Rabitsch \& Essl 2009).

Despite the distinctly mountainous character of the Gesäuse, it is not the high-alpine terrain that makes up the bulk of the NP habitats, but the montane and subalpine forests $(52 \%)$. There is a wide range of forest types, depending on ground conditions and altitude, from riparian woodland along the river Enns to larch / arolla pine forests at high elevations. Intensive forestry operations made the spruce the dominant tree species in the past. Currently efforts are under way to affect a gradual shift towards a fitting combination of species for the locality (Holzinger \& Haseke 2009).

Nine traditional mountain pastures in the NP are still being stocked today. This cultural landscape is used with conservation in mind and the rich interpolation of habitats means a particularly high species diversity.

The river Enns is the sensitive spine of Gesäuse NP. It is fed by the brooks Johnsbach and Hartelsbach, by temporarily acquiferous ditches and by over 650 studied springs. Johnsbach in particular transports a great amount of bed load and at the same time creates gravel bars of great conservation value.

Research and science have played an important role in the region around Admont for quite some time. The Benedictine monastery used to host well-educated clergy who, especially from the age of enlightenment onwards, strove to expand their knowledge into classic natural sciences. Father Gabriel Strobl (1846-1925) is a chief exponent. He wrote about the Flora von Admont (Strobl 1881) and laid a valuable scientific base, not just for the valley of the river Enns, but for the whole 


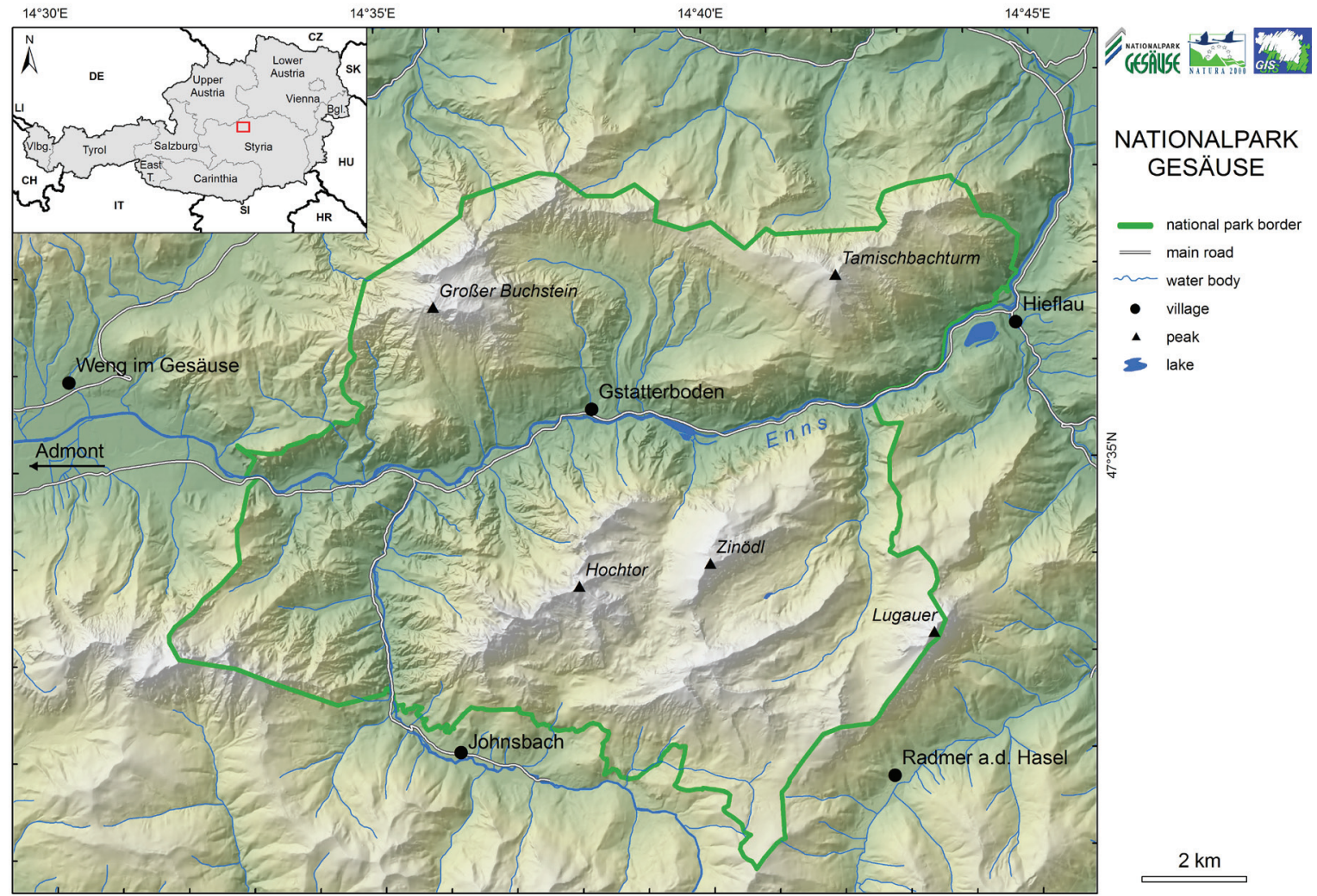

Figure 2 - Location and topography of Gesäuse NP. Map made by the authors. Data source: wnw.gis-steiermark.at 2016.

of Europe, with his extensive entomologic excursions and collections (cf. Czerny 1925; Kiefer 1941). With the creation of Gesäuse NP, a systematic exploration of the area started, consisting of basic inventories and management-related research. Even during the set-up phase of the NP, the association Verein Nationalpark Gesäuse and its successor Nationalpark Planungs $\mathrm{GmbH}$ commissioned numerous pieces of research. The LIFE nature project Naturschutzstrategien für Wald und Wildfluss im Gesäuse (Conservation strategies for woodland and rivers in the Gesaeuse), which ran from 2005 to 2011, tackled numerous challenges for the young national park. Today's work is based on a range of management plans and measures (Haseke \& Kreiner 2011). Basic inventories on flora and fauna are summarized in Kreiner \& Maringer (2012).

\section{Material and methods}

The presented analysis of the research reports covers the decade from the establishment of Gesäuse NP (2003-2013) and the so-called NP planning area (around $12000 \mathrm{ha}$ ) and its immediate surroundings. In addition some papers that go beyond the region or the protected area were included if Gesäuse NP was the object of the study.

The texts were analysed along criteria derived from the Austrian National Park Strategy (BMLFUW 2010), which had already been consulted when the research concept for Gesäuse NP was created (Maringer \& Kreiner 2013). As the area is an important stepping stone within the Natura 2000 network, the analysis pays particular attention to species and habitats of the Habitats Directive (Council Directive 92/43/EEC) and to species of the Birds Directive (Council Directive 2009/147/EC).

\section{Results}

Applying these criteria we captured 503 completed research publications. Of these, 194 were published in the series Schriftenreibe des Nationalparks Gesäuse (Vol. 1-10). Most of these are popular-science communications of research and of the results of the annual GEO-Tage der Artenvielfalt (species diversity days). Because of the great overlap with the original papers, we excluded these texts from the analysis. This left 309 re-

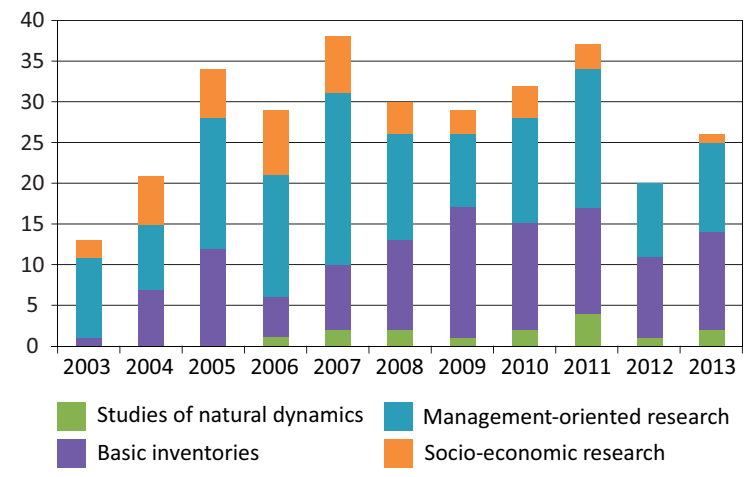

Figure 3 - Distribution of the analysed papers across research areas per year. $N=309$. 


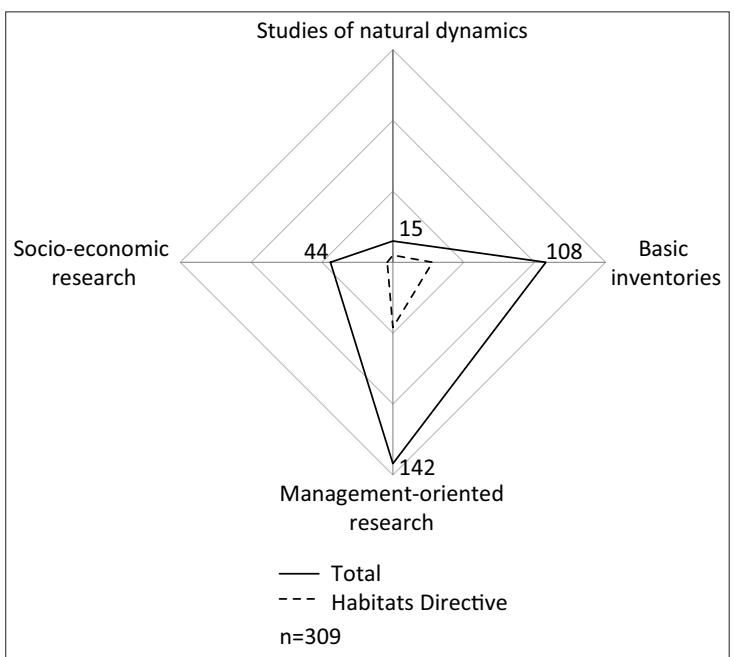

Figure 4 - Research focus in Gesänse NP 2003-2013.

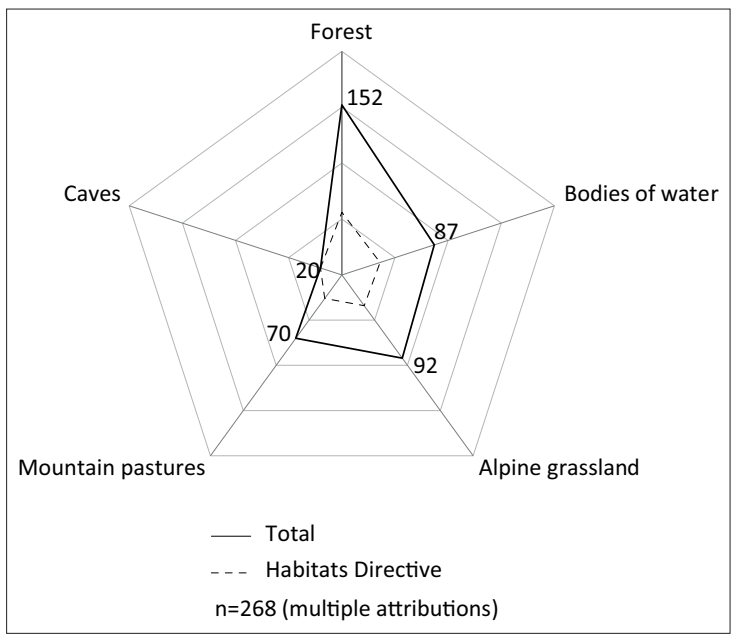

Figure 5 - Investigated habitat types Gesäuse NP 2003-2013.

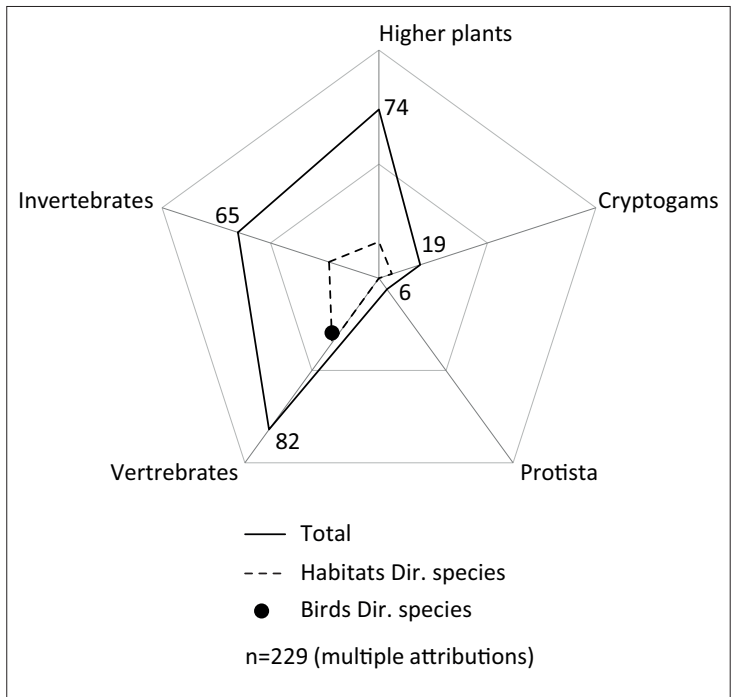

Figure 6 - Investigated higher taxa in Gesäuse NP 2003 2013. search papers created by a total of 366 authors within the chosen period.

On average 30.9 (13-38) research papers were completed per year. 2007 was the year with the most publications, with a considerable proportion stemming from the EU-funded LIFE project Management von Wald und Wildfluss im Gesäuse 2005-2010 (LIFE05 NAT/A/000078).

Half of the papers $(49.8 \%)$ were commissioned and funded in full by Nationalpark Gesäuse $\mathrm{GmbH}$. Another $45.3 \%$ were partly funded by them. Further funding came from the federal province of Styria, from Interreg IIIb (Alpine Space) and LIFE.

\section{Research areas}

In Gesäuse NP most of the research (46.0\%) is management-oriented. A third $(35.0 \%)$ of resources are directed at capturing the basic assets (species inventories, habitat mapping, etc.) (Figure 4).

268 of the 292 research papers could be attributed to one or more investigated habitats (Figure 5). A clear focus on forests emerges here (36.1\%). 40.9\% of the papers relate directly to a relevant habitat of the Habitats Directive.

Research in Gesäuse NP is aimed at vertebrates $(33.3 \%)$ and higher plants $(30.1 \%)$, as well as invertebrates $(26.4 \%)$. Protista and cryptogams are underrepresented. In $46.7 \%$ of the studies the papers refer to species relevant to the Habitats and the Birds Directive (Figure 6).

274 papers came from single-discipline researches. 35 papers $(11.3 \%)$ stemmed from multi- or transdisciplinary projects, for instance the results of the pilot project Sulzkaralm (e. g. Drescher-Schneider 2007; Frieß \& Derbuch 2005; Hasitschka 2004; Schwab et al. 2003; Weigand \& Graf 2004) or the development of the Leitlinie Enns (Enns guidelines) (Hohensinner et al. 2008). In some cases (Gerecke 2009, 2010, 2012) this included international groups of researchers.

The bulk of the commissioned research $(57.6 \%)$ was completed within a year or a season. $35.9 \%$ of research projects did not exceed four years. 15 projects $(4.9 \%)$ had a duration of more than seven years (Figure 7).

\section{Researchers}

In fulfilling its research remit, the NP is able to rely on a continuously growing pool of researchers. In 2010 this numbered 223 individuals from universities, other research institutions, engineering offices as well as selfemployed researchers. The researchers are recruited in a targeted fashion by their qualifications, through calls or they submit a research proposal to the NP.

\section{Access to the research results}

Of the research papers we looked at, 22 have so far been published in peer-reviewed journals. The NP regularly publishes summarized results in its series Schriften des Nationalparks Gesäuse and makes al- 
most all papers available in full on its web pages (www.nationalpark.co.at). There are limited access papers on sensitive species of the Habitats and/or Birds Directive, for instance on orchids (Orchidacae) or grouse (Tetraonidae). All reports are entered regularly into the meta database of Nationalparks Austria (www.parcs.at).

The raw data are maintained by Nationalpark Gesäuse GmbH. Gesäuse NP does not have a scientific collection of its own. Any gathered material is stored in the relevant museums (Landesmuseum Joanneum Graz, Natural History Museum Vienna) and some of it at the researchers themselves (private collections, unprocessed material). BioOffice (Tiroler Landesmuseen 2004) is the database system used to store and maintain the data on the capture of organisms. By early 2016 it contained around 158726 records of ca. 10500 taxa (9786 species).

\section{Discussion}

On average, research efforts in Gesäuse NP lead to one completed report every 11.8 days. The bulk of the papers is oriented on bio-scientific issues. Few papers deal with technical aspects or socio-economic issues. As befits the tasks of a national park (Stmk. NPG \$2), Gesäuse NP originally, after the set-up phase, commissioned numerous projects dealing with inventory work. Out of a practical necessity the NP commissioned management-oriented research (cf. Egger \& Kreiner 2009; Holzinger \& Haseke 2009; Holzinger et al. 2012; Haseke 2006; Haseke \& Remschak 2010; Zechner 2009). Nationalpark Gesäuse GmbH carries an essential part of research funding. As budgeting is done year by year, multi-year projects are rare. Even so, Gesäuse $\mathrm{NP}$ was able to participate in long-term projects like GLORIA (Global Observation Research Initiative in Alpine Environments; Klipp 2010) and LTER (Long Term Ecological Research; Mirtl et al. 2015).

The projects cover the typical research areas of a strict conservation area listed by Vilsmaier (2010) and include some transdisciplinary approaches.

Gesäuse NP puts its research emphasis on creating inventories and on long-term monitoring of natural processes and protected assets in the park, on evaluating and improving management measures, on investigating the long-term effect and response to its visitor and educational programmes and on presenting the impact of the NP, especially in the region (Maringer \& Kreiner 2013). These aims are mostly in line with those of other Central European NPs where such a concept has been developed in recent years (Forschungskommission SNP 2008; Bauch et al. 2007) and are derived from the guidelines of the International Union for Conservation of Nature (Dudley 2008) for national parks of IUCN Category II.

In future increased attention will be paid to investigating natural dynamics and zoological and botanical peculiarities. Initial projects with a long-term per-

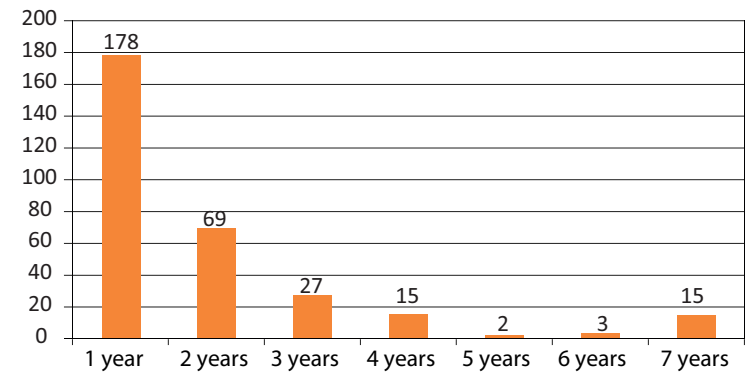

Figure 7 -Duration of research projects in the Gesäuse NP 2003-2013.

spective have already started (Jungmeier et al. 2014, 2015; Ökoteam 2014). Short-term management issues and ecologic long-term research must not be opposites (Dröschmeister \& Gruttke 1998) but are needed jointly in the work at the NP. Management-oriented research will continue to guide the measures to be taken to attain long-term goals in the protected area.

Today the park management benefits from an already large knowledge pool created by this research. The section responsible for conservation and research condenses the results further and interweaves them to provide the sections habitat management, forest management or wildlife management and the section responsible for ecologic education with the required facts for their decision making. Research papers are highly relevant for the protected area and quickly find their way into the management of the NP. One challenge for Austria's youngest NP is the structured maintenance of the generated results and data, making them available and saving them for future generations. In 2013 all Austrian NPs began to harmonize their knowledge management in a joint project and will develop it further.

Researchers who are well connected with the protected area play an important role in generating knowledge of relevance to the management (Wilgen et al. 2015). In Gesäuse NP most of the research is carried out by external contractors. As many of them have worked repeatedly in the protected area, good networking has evolved with the NP as well as between researchers and has encouraged debate and sharing of scientific insights. In this way the foundations have been laid and secured with research findings, qualitative and quantitative results to support the management in their work.

NP research has been successfully established within university research. The cooperation with mainly Austrian universities is reflected in 42 pre-scientific papers. The reach of the findings is rather small, given the low number of publications in peer-reviewed journals. Further papers may still be held in an extensive review process or get published after the end of a longer-term project.

From our analyses of the research environment and from internet and library enquiries we conclude 
that the proportion of not well known papers is likely to be small. Active cooperation with the protected area management is supported by the option to submit research proposals and get funding and by the NP being able to supply environmental data, maps and raw data from other studies.

Research in the NP avoids very invasive or ethically dubious methods of insufficiently known consequences (Maringer \& Kreiner 2013). Preferred methods are non-intrusive and minimal-invasive, supported by computer models and the interpretation of aerial photographs (Hauenstein et al. 2013). The NP is an exciting study area for many disciplines. At the same time it is a sensitive research area subject to limitations if it is to fulfil its purpose in the longer term. The NP administration will continue to actively guide research activities, but via research proposals scientists from all disciplines may actively contribute to the study and development of Gesäuse NP.

\section{Acknowledgements}

The authors wish to thank all researchers that have been active in Gesäuse NP so far for their valuable work. We also thank the numerous experts who make themselves available to us for discussions and pieces of advice throughout the year. Our thanks also go to all those who volunteer to participate in the GEO-Tage der Artenvielfalt and who have expanded our knowledge of the species diversity in the area.

\section{References}

All analysed papers are available on www.parcs.at.

Adams, W.M. \& C. Sandbrook 2013. Conservation, evidence and policy. Oryx 47(03): 329-335. DOI: 10.1017/S0030605312001470

Bauch, K., M. Jungmeier \& S. Lieb (eds.) 2007. Forschungskonzept Nationalpark. Hohe Tauern 2020. [In German]

BMLFUW 2010: Österreichische Nationalpark-Strategie - Ziele und Visionen von Nationalparks Austria. Bundesministerium für Land- und Forstwirtschaft, Umwelt und Wasserwirtschaft. Wien. [In German]

Czerny, L. 1925. Prof. P. Gabriel Strobl. Konowia (Vienna). Beiträge zur systematischen Insektenkunde 4(6): 376-381. Wien. [In German]

Drescher-Schneider, R. 2007. Spät- und postglaziale Vegetationsentwicklung im Oberen Moor - Sulykaralm. Im Auftrag der Nationalpark Gesäuse GmbH. Kainbach bei Graz. [In German]

Dröschmeister, R. \& H. Gruttke (eds.) 1998. Die Bedeutung ökologischer Langzeitforschung für Naturschutz. Bundesamt für Naturschutz. Schriftenreihe für Landschaftspflege und Naturschutz 58. Bonn-Bad Godesberg. [In German]

Dudley, N. (ed.) 2008. Guidelines for Applying Protected Area Management Categories. Gland, Switzerland: IUCN.
Stolton, S., P. Shadie \& N. Dudley 2013. IUCNWCPA. Best Practice Guidance on Recognising Protected Areas and Assigning Management Categories and Governance Types. Best Practice Protected Area Guidelines Series 21. Gland, Switzerland.

Egger, G. \& D. Kreiner 2009. Managementplan Almen. Naturschutzstrategien für Wald und Wildfluss im Gesäuse. Nationalpark Gesäuse GmbH. LIFE05 NAT/A/000078. Weng im Gesäuse. [In German]

Forschungskommission SNP 2008. Forschungskonzept 2008-2018 für den Schweizerischen Nationalpark. und die Biosfera Val Müstair. [In German]

Frieß, T. \& G. Derbuch 2005. Zoologische Kartierung Sulzkaralm, NP Gesäuse - Fachbereich Insekten - Heuschrecken \& Wanzen. [nventarisierung und Pflegemanagement]. Institut für Naturschutz, Steiermark. Im Auftrag der Nationalpark Gesäuse GmbH. Graz. [In German]

Gerecke, R. 2009. Quellprojekt Nationalpark Gesäuse - 2. Quellwoche 2008. Im Auftrag der Nationalpark Gesäuse GmbH. Tübingen. [In German]

Gerecke, R. 2010. Quellprojekt Nationalpark Gesäuse - 4. Quellwoche 2010. Im Auftrag der Nationalpark Gesäuse GmbH. Tübingen. [In German]

Gerecke, R., H. Haseke, J. Klauber \& A. Maringer (eds.). Schriften des Nationalparks Gesäuse 7. Weng im Gesäuse. [In German]

Haseke, H. \& D. Kreiner 2011. LIFE Gesäuse. Final Report. Naturschutzstrategien für Wald und Wildfuss im Gesäuse. Nationalpark Gesäuse. Weng. [In German]

Haseke, H. 2006. A2 Managementplan Revitalisierungsprojekt Johnsbach-Zwischenmäuer 2006-2008. LIFE05 NAT/A/000078. Nationalpark Gesäuse GmbH. LIFE05 NAT/A/000078. Weng im Gesäuse. In German]

Haseke, H. \& C. Remschak 2010. Managementplan Neobiota. Im Auftrag der Nationalpark Gesäuse GmbH. Weng im Gesäuse. [In German]

Hasitschka, J. 2004. Die Geschichte der Sulzkaralm. Im Auftrag der Nationalpark Gesäuse GmbH. Admont. [In German]

Hauenstein, P. \& R. Haller 2013. CC-Habitalp: ChangeCheck of the Habitats of the Alps. Semantik, Logik und technischer Aufbau eines Änderungskartierschlüssels auf Stufe Landschaftfür Schutzgebiete in den Alpen. Bern. [In German]

Holzinger, A. \& H. Haseke (eds.) 2009. A3 Managementplan Wald. LIFE05 NAT/A/000078, Naturschutzstrategien für Wald und Wildfluss im Gesäuse. Im Auftrag der Nationalpark Gesäuse GmbH. Weng im Gesäuse. [In German]

Holzinger, A., H. Haseke \& E. Stocker (eds.) 2012. Managementplan Witterschutt und Geschiebe. Im Auftrag der Nationalpark Gesäuse GmbH. Weng im Gesäuse. [In German]

Hohensinner, S., S. Muhar, M. Jungwirth, G. Pohl \& M. Stelzhammer 2008. Leitlinie Enns. Schwerpunktbereich Paltenmündung - Hieflau. Wien. [In German]

Jungmeier, M., H. Kirchmeir, C. Hecke \& D. Kreiner 2016. Naturprozesse in einem Lawinarsystem - das 
Beispiel Kalktal im Nationalpark Gesäuse (Ennstaler Alpen, Tamischbachturm). Mitteilungen des Naturwissenschaftlichen Vereines für Steiermark 45: 17-31. Graz. [In German]

Jungmeier, M., C. Hecke \& T. Köstl 2015. Dokumentation von Naturprozessen im Nationalpark Gesäuse Teil 2: Gewässerdynamik am Johnsbach. Endbericht. E.C.O. Institut für Ökologie. Im Auftrag der Nationalpark Gesäuse GmbH. Klagenfurt. [In German]

Kiefer, H. 1941. Gabriel Strobl und sein Lebenswerk. Zeitschrift des Wiener Entomologen-Vereines 26: 186 191. Wien. [In German]

Klipp, M. 2010. GLORIA - der Weg der Pflanzen in den Himmel. In: Kreiner, D. \& L. Zechner (eds), In böheren Lagen. Schriften des Nationalparks Gesäuse 5: 22-27. [In German]

Kreiner, D. \& A. Maringer A. (eds.) 2012. Erste Dekade. Schriften des Nationalparks Gesäuse 9. Weng. [In German]

Maringer A. \& D. Kreiner 2013. Forschungskonzept 2013-2023. Im Auftrag der Nationalpark Gesäuse $\mathrm{GmbH}$. Weng im Gesäuse. [In German]

Mirtl, M., M. Bahn, T. Battin, A. Borsdorf, T. Dirnböck, M. Englisch, B. Erschbamer, J. Fuchsberger, V. Gaube, G. Grabherr, G. Gratzer, H. Haberl, H. Klug, D. Kreiner, R. Mayer, J. Peterseil, A. Richter, S. Schindler, A. Stocker-Kiss, U. Tappeiner, T. Weisse, V. Winiwarter, G. Wohlfahrt \& R. Zink 2015. Research for the Future - LTER-Austria White Paper 2015 - On the status and orientation of process oriented ecosystem research, biodiversity and conservation research and socio-ecological research in Austria. LTER-Austria Series 2.

Ökoteam 2014. 3 Zoologische Rätsel zur Endemitenfauna im Nationalpark Gesäuse. Tiergruppen: Weberknechte, Wanzen \& Zikaden. Ökoteam. Im Auftrag der Nationalpark Gesäuse GmbH. Graz. [In German]

Rabitsch, W. \& F. Essl 2009. Endemiten - Kostbarkeiten in Österreichs Pflanzen- und Tierwelt. Naturwissenschaftlicher Verein für Kärnten, Klagenfurt und Umweltbundesamt, Wien. [In German]

Schwab, M., F. Bergler \& G. Egger 2003. Almbewirtschaftungsplan Sulzkaralm. Nationalpark Gesäuse. Im Auftrag der Nationalpark Gesäuse GmbH. [In German]

Stmk. NPG 2002. Gesetz vom 12. März 2002 über den Nationalpark Gesäuse (Nationalparkgesetz Gesäuse) LGBl. Nr. 61/2002. [In German]
Strobl, G. 1881. Flora von Admont (Teil I-III). The Biodiversity Heritage Library. Available at: DOI: http://dx.doi.org/10.5962/bhl.title.9816 (accessed 25/03/2016) [In German]

Tiroler Landesmuseen 2004. BioOffice v2.0.10. Software. Available at: http://www.biooffice.at/ (accessed 25/03/2016)

Van Wilgen, B.W., N. Boshoff, I.P.J. Smit, S. SolanoFernandez \& L. Van der Walt 2016. A bibliometric analysis to illustrate the role of an embedded research capability in South African National Parks. Scientometrics: 1-28. DOI 10.1007/s11192-016-1879-4

Vilsmaier, U. 2010. Transdisciplinarity and protected areas: A matter of research horizon. eco.mont 2(2): 37-44. doi:10.1553/eco.mont-2-2s37

Weigand, E. \& W. Graf 2004. Hydrobiologische Erstcharakterisierung bedeutender Karstquellen der Sulzkaralm ( $\mathrm{Na}$ tionalpark Gesäuse). Pilotprojekt Sulzkaralm. Teilprojekt. Im Auftrag der Nationalpark Gesäuse GmbH. Weng im Gesäuse. [In German]

Zechner, L. 2009. Managementplan Besucherlenkung. Nationalpark Gesäuse GmbH. Im Auftrag der Nationalpark Gesäuse GmbH. Weng im Gesäuse. [In German]

\section{Authors}

\section{Alexander Maringer ${ }^{1}$}

specialized on beavers and worked on nature conservation, GIS modelling and environmental education before starting at Gesäuse NP in the year 2011. Since then he has been responsible for zoological and wildlife issues in the NP, with an additional focus on information management. E-mail: alexander.maringer@nationalpark.co.at

\section{Daniel Kreiner ${ }^{\top}$}

worked on habitat mapping and evaluation, GIS mapping and modelling. In 2003 he became Head of Department for nature conservation and research in Gesäuse NP. He has a special interest in the effects of land-use change (historical analyses) and nature conservation management (non-intervention versus intervention). E-mail: daniel.kreiner@nationalpark.co.at

\footnotetext{
${ }^{1}$ Nationalpark Gesäuse, Fachbereich Naturschutz \& Naturraum, 8913 Admont www.nationalpark.co.at
} 